\title{
STUDY OF MOTIVATION TYPES OF ENGLISH-MAJORING STUDENTS AND DEMOTIVATING FACTORS - IN THE CONTEXT OF NATIONAL UNIVERSITY OF MONGOLIA, ERDENET SCHOOL
}

\author{
Solongo Shagdarsuren *, Ulambayar Batchuluun, Daniel Lindbergh Lang \\ National University of Mongolia, Erdenet School, Mongolia \\ ${ }^{*}$ E-mail: Solongo21@yahoo.com
}

\begin{abstract}
A decline in number of credit hours of English courses for English-majoring students at National University of Mongolia is forcing teachers and students to focus on how to learn English more effectively and what factors would affect that process within credit hours allowed at the university. However, the English teaching class hours in Mongolian secondary schools have been increasing for the last few years, due to the interest in learning English as a foreign language, and resulting in a growth in the demand for English teachers. This study has a goal to investigate into motivation of English-majoring students towards learning English and the factors affecting them to be demotivated. Twenty students studying English as a major at National University of Mongolia, Erdenet School completed the research questionnaire which intended to discover English learning motivation through 12 items and attended focus group interview with 5 questions to find internal and external demotivating factors in 2019-2020 academic year. The students had instrumental orientation and demonstrated a strong desire to learn English. Furthermore, they were demotivated by their teachers' and classmates' attitudes and living conditions. The researchers suggested some recommendations based on the study findings.
\end{abstract}

Key words: learning motivation, instrumental motivation, integrative motivation, demotivation, internal factors, external factors

\section{INTRODUCTION}

The Nesta report (Bakhshi, et al. 2017) estimated that English knowledge is listed at $21^{\text {st }}$ (US) and $34^{\text {th }}$ (UK) of the 120 skills, knowledge and ability, which is high in rank and shows that development of science, technology, and social areas will be done and delivered or introduced in English.

Landlocked between Russian Federation and People's Republic of China, Mongolia, a former socialist country before 1990, had a democratic revolution shifting it to a democratic country. This political and social situation brought people of Mongolia to develop foreign relations and communication, which was an essential reason of paying attention to the second foreign language, after Russian, nationwide. English has been among the most important subjects in Mongolian schools since its teaching began in the 1992-1993 academic year. A further change to English language education was implemented with the 
victory of the Mongolian People's Revolutionary Party (MPRP) in the national election of 2000 (Cohen 2004). The newly elected parliament drafted a white paper stating that English should receive further emphasis in the education system due to Mongolia's integration with the world economy, the rise of tourism and the overall benefits of studying the primary international language. The Mongolian government mandated that whenever possible, students should begin studying English in the fourth grade, and that all English students should continue studying in the newly added eleventh grade in the 2005-2006 academic year (Shagdarsuren and Davaasuren 2017).

Shagdarsuren and Davaasuren (2017) estimated that English class hours in secondary school level have been increasing from 655 to 700 for 6-7 years and reaching 840 hours of English lesson in 2008. Furthermore, Ministry of Education, Culture, Science and Sports declared an increase in English class hours in secondary schools including 99 academic hours for $5^{\text {th }}$ graders (MES 2014), from $6^{\text {th }}$ to $9^{\text {th }}$ grade -420 hours, (MECSS 2015), for upper-secondary level or $10^{\text {th }}-12^{\text {th }}$ grades -387 hours, which totals up to 906 hours of English classes, which are compulsory and can be added by 387 academic hours or 9 credit hour as elective lesson (MECSS 2016). In secondary schools, normative workload of English teachers, determined by the corresponding ministry is 19 hours per week and academic year continues for 33 weeks which makes 627 hours for per English teacher. All these pre-conditions and the situation in Mongolia brought up new perspective at English as a new foreign language and a great demand of English teachers in the job market, influencing secondary school students to choose English teacher programs as their future majors.

National University of Mongolia (NUM), and Mongolian State University of Education are state universities which prepare English teachers, except private colleges and universities in Mongolia. NUM, Erdenet School, operating in a rural area, is the sole state university, offering Teacher, Foreign language Education (English) in Khangai Region. Students enrolled at this program are from the Khangai region and Central region of Mongolia inclusive 11 aimags. Approximately 22 students graduate every year and they become the major workforce of the same regions.

The study plan of English teacher's program at NUM, Erdenet School before 2014, consisted of 80 credit hour of English courses, which is $64 \%$ of 125 credit hours in total. In 2014, the Minister of the Education, Culture and Science (2014) passed a decree that states students graduating with a bachelor's degree from universities need to pass an upper-intermediate level of English. In the same decree, it declares the total credit hours to be accomplished must be at least 120 credit hours in 4 years of bachelor degree program. The requirement of minimum 120 credit hours includes $30 \%$ of compulsory courses of general basic programs 6 credit hours of English within, and professional basis and professional subjects be $70 \%$ (Mongolian Ministry of Education 2014), which was a huge decline in the number of courses and credit hours of English. Since the corresponding ministry made the decision, it applied to NUM and required to change the all program study plans (Ministry of Education 2019), including that of English teachers' program. As a result, the credit hours of English courses for English teacher's program dropped to 51 and it is calculated to be $42.5 \%$ of 120 credit hours.

In this contrastive condition where English teachers demand is high, but English course hours at universities is decreasing, it is essential to focus on what motivation students who are majoring as English teachers have and find out factors demotivate them. 


\section{LITERATURE REVIEW}

Maslow (1943) made an attempt to define motivation theory and offered hierarchy of needs including self-actualization, esteem, love and belonging, safety needs and physiological needs. Gray and Klapper (2009) offered that understanding the role of affective factors emphasizing motivation is among the most important of four essential elements of understanding how languages are learnt, identifying preferred learning style, understanding the role of affective factors, and being involved in shaping the course, to learn and teach English. Gardner (2007) explained that motivation affects the process of learning a second language, as specific motivation exists toward language classes or other language learning situations. Student motivation is the element that leads students' attitudes towards the learning process (Afzal, et al. 2010). William and Burden (1997) proposed definition of motivation construed as a state of cognitive and emotional arousal which leads to a conscious decision to act and which gives rise to a period of sustained intellectual and/or physical effort in order to attain a previously set goal (or goals).

Gardner and Lambert (1972) divided the motivation type into two categories, and Gardner defined them as integrative and instrumental motivation. There is a relationship between motivation and orientation, which he stated to be a collection of reasons that reflect common or conceptually similar goals (Gardner 2001). Instrumental orientation is the purpose of language study that reflects the more utilitarian value of linguistic achievement, such as getting ahead in one's occupation (Gardner and Lambert 1972). In contrast, integrative orientation encompasses students' wishes to learn more about another cultural community because of their interests in a more open-minded way, to the point of eventually being accepted as a member of that group (Gardner and Lambert 1972).

Motivation is a base factor affecting students' academic performance at the university level (Chen, 2014; Klimova, 2011; Ozuturk \& Hursen, 2014). Motivation to do something is influenced by a range of factors, some of which are internal to the learner and some external (William and Burden 1997). Zangbar (2012), who studied undergraduate Libyan students majoring in English had unusual findings. Students had both high instrumental and integrative motivations, the integrative motivation appeared slightly higher than instrumental one, and the students' motivations had no relationship with their academic achievement. William and Burden (1997) offered a motivation model which reflects the dynamic interaction between the different internal and external variables leading to the decision to act as it is the way learners make sense of the factors surrounding by them.

On other hand, Dorneyi and Ushioda (2011) defined factors affecting motivation and demotivation. They defined demotivating factors as "specific external forces that reduce or diminish the motivational basis of a behavioral intention or an ongoing action" (Dorneyi and Ushioda 2011). In other words, demotivation encompasses when students have no interest or intention to learn.

Ali and Pathan (2017) aimed to find factors of demotivation in students and listed grammar-based teaching, classroom environment, effect of low test scores, teachers' behavior, course contents and teaching materials, lack of self-confidence and interest. Dorneyi (2001) revealed factors affecting demotivation among 50 students, by interviewing for 10-30 minutes. Factors were teachers, reduced self-confidence, inadequate school facilities, negative attitudes toward L2, the compulsory nature of L2, interference of another language, negative attitudes towards the L2 community, attitudes of group members, and the course book. According to Chambers (1993), teachers could be among the most 
demotivating factors for students to learn English. Kikuchi and Sakai (2009) surveyed 112 learners of English from universities in Japan. The scholars identified demotivating factors such as (a) course books, (b) inadequate school facilities, (c) test scores, (d) noncommunicative methods, and (e) teachers' competence and teaching styles in their questionnaire. Jung (2011) conducted a survey among Korean college students about the demotivating factors and found out that, in general, external factors were more involved in the demotivation process for the students.

\section{MethodolOGY}

\subsection{Research questions}

The researchers aimed to find answers to following questions:

1. Is the motivation orientation of students who are English-majoring integrative or instrumental?

2. What are the motivating and demotivating factors affecting students learning English?

\subsection{Research sample}

Twenty undergraduate students studying to be English teachers at National University of Mongolia, Erdenet School, the Department of Humanities, participated. There were sixteen were sophomores, and four were seniors, aged 18-24.

Table 1 Age and gender distribution of participants

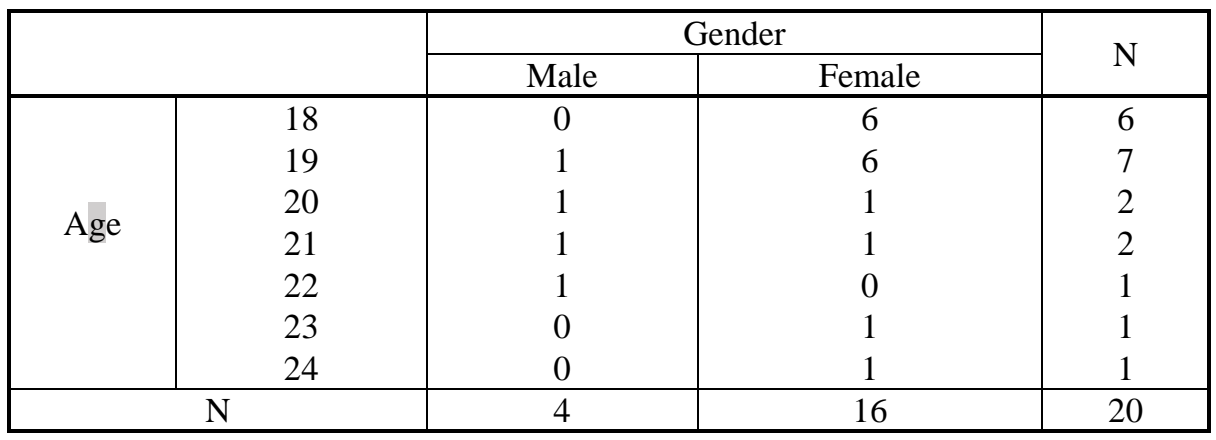

\section{INSTRUMENT AND PROCEDURE}

\subsection{Questionnaire}

We surveyed students at the end of first term of the 2019-2020 academic year. Researchers used MINI-AMTB, an adapted version of the questionnaire Attitude Motivation Test Battery, developed by Gardner (2004) as a research instrument. Although the study participants were students of English teacher's class, we translated the questionnaire into Mongolian, considering the relevance and convenience for the students whose first language is Mongolian. The questionnaire consisted of two parts. The first part was constructed to collect demographic information such as age, gender, academic level, and the second part 
consisted of 12 items dedicated to find out interest in foreign language, motivational intensity, English class anxiety, English teacher evaluation, attitudes toward learning English, attitudes toward English-speaking people, desire to learn English, English course evaluation, English use anxiety, integrative and instrumental orientation of the students.

Each question, students had to rate on a scale $1-7 ; 1$ is weak, unfavorable, very little and low, whereas 7 stands for strong, favorable, very much and high (Table 2). Before students started answering, they were reminded not to worry and to feel relaxed to deliver their answers based on their opinion and evaluation.

Table 2 Content of the Questionnaire

\begin{tabular}{|c|c|c|}
\hline Question to discover & Items in the questionnaire & Rating \\
\hline Integrative orientation & $\begin{array}{l}\text { My motivation to learn English in } \\
\text { order to communicate with } \\
\text { English speaking people is: }\end{array}$ & $\begin{array}{l}\text { Weak__ 1:__ 2:_3:_4 } 4: \ldots 5: \_6: \ldots \\
7 \text { Strong }\end{array}$ \\
\hline $\begin{array}{l}\text { Attitudes toward } \\
\text { English-speaking people }\end{array}$ & $\begin{array}{l}\text { My attitude toward English } \\
\text { speaking people is }\end{array}$ & 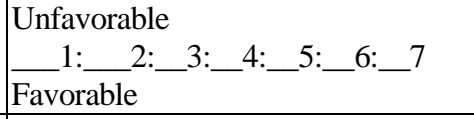 \\
\hline $\begin{array}{l}\text { Interest in foreign } \\
\text { language }\end{array}$ & $\begin{array}{l}\text { My interest in foreign languages } \\
\text { is }\end{array}$ & 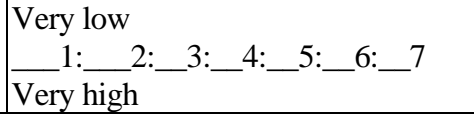 \\
\hline Desire to learn English & My desire to learn English is & $\begin{array}{l}\text { Weak__1:_2:_3:_4:_5:_6: } \\
\text { 7 Strong }\end{array}$ \\
\hline $\begin{array}{l}\text { Attitudes toward } \\
\text { Learning English }\end{array}$ & $\begin{array}{l}\text { My attitude toward learning } \\
\text { English is }\end{array}$ & $\begin{array}{l}\text { Unfavorable } \\
\quad 1: \quad 2: \quad 3: \_4:\left[5: \_6: \_7\right. \\
\text { Favorable }\end{array}$ \\
\hline $\begin{array}{l}\text { English Teacher } \\
\text { Evaluation }\end{array}$ & $\begin{array}{l}\text { My attitude toward my English } \\
\text { teacher is }\end{array}$ & 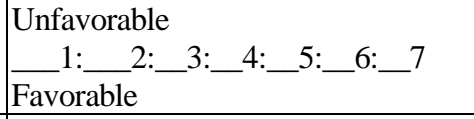 \\
\hline Instrumental orientation & $\begin{array}{l}\text { My motivation to learn English } \\
\text { for practical purposes (e.g., to get } \\
\text { a good job) is }\end{array}$ & $\begin{array}{l}\text { Weak } \\
\text { 1:___ 2:_3:_4:_5:_6:_7 }\end{array}$ \\
\hline English use Anxiety & $\begin{array}{l}\text { I worry about speaking English } \\
\text { outside of class }\end{array}$ & 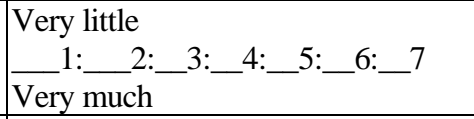 \\
\hline $\begin{array}{l}\text { English course } \\
\text { evaluation }\end{array}$ & $\begin{array}{l}\text { My attitude toward my English } \\
\text { course is }\end{array}$ & 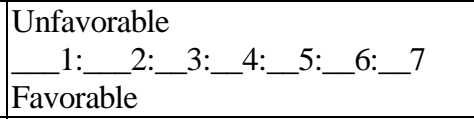 \\
\hline English class anxiety & $\begin{array}{l}\text { I worry about speaking in my } \\
\text { English class }\end{array}$ & $\begin{array}{l}\text { Very little } \\
\quad 1: \quad 2: \quad 3:-4:\left[5: \_6: \_7\right. \\
\text { Very much }\end{array}$ \\
\hline Motivational intensity & My motivation to learn English is & 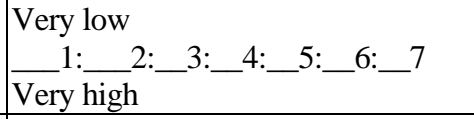 \\
\hline Parental encouragement & $\begin{array}{l}\text { My parents encourage me to } \\
\text { learn English }\end{array}$ & 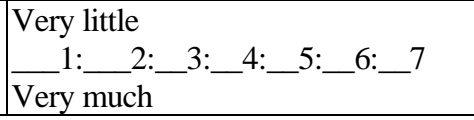 \\
\hline
\end{tabular}




\subsection{Focus group interview}

As the second part of the study after the questionnaire, researchers conducted a focus group interview in Mongolian among the same sample size of 20 students, 4 male and 15 female students, on the same day as the questionnaire. The interview aimed to find out students' opinion on the significance of English, the reasons of studying English, common factors affecting motivation and demotivation in learning English and if any changes would occur if English is acquired in advanced level, with following question items:

1. What is the significance of English?

2. Why are you studying English?

3. What are your internal and external demotivating factors toward learning English?

4. What outcomes do you expect after learning English?

5. Do you believe the attitudes from other people would change if you learnt English well?

The first two question items were warm-up questions for participants, to make them ready for the important items. The third was the key item from the interview, whereas the items 4 and 5 were the follow-up questions.

Two of researchers, who are Mongolians, conducted the focus group as moderators. We prepared the classroom and seats in advance (Krueger and Casey 2015). In order to create warm and relaxed atmosphere, one of the researchers explained the interview goal and asked students to feel free to express their opinions, thoughts and real conditions they encounter in school. One moderator conducted the interview and started with warm-up questions to lead to the follow-up questions about demotivating factors. The other moderator took notes and recorded the interview. The focus group interview continued for 60 minutes.

\section{RESULTS}

\subsection{Questionnaire}

We conducted the questionnaire reliability analysis using IBM SPSS v.23 program and calculated means and standard deviations among other analytics.

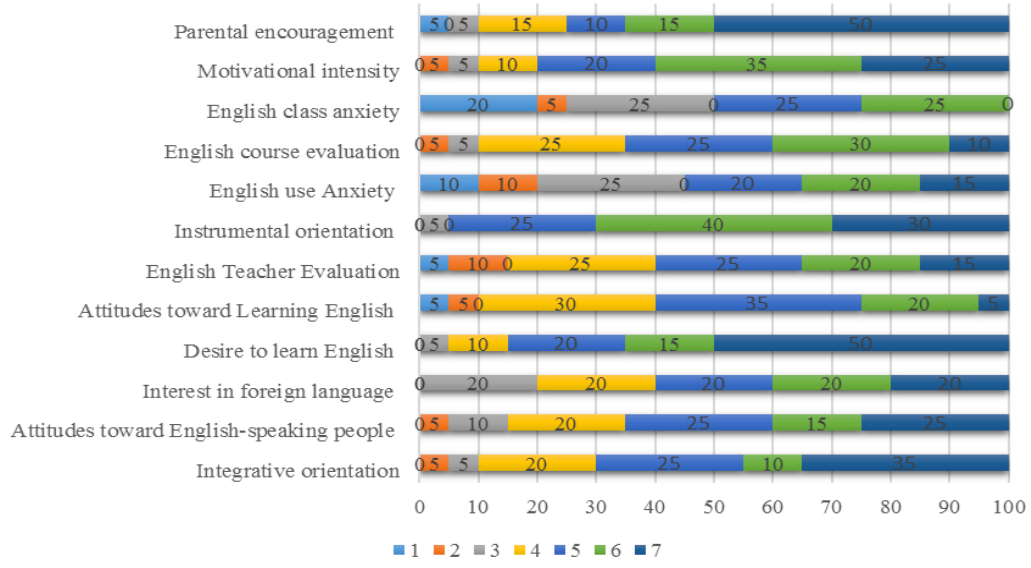

Chart 1 Questionnaire results percentage 
Table 3 Descriptive Statistics

\begin{tabular}{|l|c|c|c|c|c|c|c|}
\hline & $\mathrm{N}$ & Range & Minimum & Maximum & \multicolumn{2}{|c|}{ Mean } & $\begin{array}{c}\text { Std. } \\
\text { Deviation }\end{array}$ \\
\cline { 2 - 8 } & Statistic & Statistic & Statistic & Statistic & Statistic & $\begin{array}{c}\text { Std. } \\
\text { Error }\end{array}$ & Statistic \\
\hline Integrative orientation & 20 & 5.00 & 2.00 & 7.00 & 5.3500 & .34240 & 1.53125 \\
Attitudes toward & 20 & 5.00 & 2.00 & 7.00 & 5.1000 & .33950 & 1.51831 \\
English-speaking people & & & & & & & \\
Interest in foreign language & 20 & 4.00 & 3.00 & 7.00 & 5.0000 & .32444 & 1.45095 \\
Desire to learn English & 20 & 4.00 & 3.00 & 7.00 & 5.9500 & .28539 & 1.27630 \\
Attitudes toward Learning & 20 & 6.00 & 1.00 & 7.00 & 4.6500 & .31014 & 1.38697 \\
English & & & & & & & \\
English teacher Evaluation & 20 & 6.00 & 1.00 & 7.00 & 4.7500 & .37609 & 1.68195 \\
Instrumental orientation & 20 & 4.00 & 3.00 & 7.00 & 5.9000 & .22827 & 1.02084 \\
English use Anxiety & 20 & 6.00 & 1.00 & 7.00 & 4.3000 & .44780 & 2.00263 \\
English course evaluation & 20 & 5.00 & 2.00 & 7.00 & 5.0000 & .29019 & 1.29777 \\
English class Anxiety & 20 & 5.00 & 1.00 & 6.00 & 3.8000 & .42674 & 1.90843 \\
Motivational intensity & 20 & 5.00 & 2.00 & 7.00 & 5.5000 & .31204 & 1.39548 \\
Parental encouragement & 20 & 6.00 & 1.00 & 7.00 & 5.7000 & .38457 & 1.71985 \\
\hline
\end{tabular}

The table 3 shows students' instrumental orientation (5.900) and integrative orientation (5.300) are high. But the difference between the two orientations is 0.600. In other words, students have higher instrumental motivation that integrative orientation. The 'Desire to learn English' item mean is the highest, at 5.9500. The lowest items scored were English use anxiety (4.3000) and English class anxiety (3.8000). Furthermore, parental encouragement and motivational intensity are rather high.

\subsection{Focus group interview}

Researchers asked participants to respond to the questions one by one and take turns and the interview result was explained below, in accordance with the focus group interview items list. For the first question, students commented on English being an important language and means of communication to receive information, to travel and live abroad, to learn and get educated, and to socialize. The second question was "Why are you studying English?" and the participants responded they are learning English since it is their major, they take compulsory courses, it is a global language, and because their parents demanded them to study English. They added that most scientific and professional documents and materials are written in English. For the key item of the interview, students gave answers related to teachers' and other students' attitudes. We translated these from Mongolian into English.

The teacher's attitude makes me stop studying English. Sometimes they say you cannot graduate as English teachers.

Sometimes teachers get frustrated when we don't get the lesson.

When I read or pronounce some words wrong, some students giggle, and I feel uncomfortable. 
Moreover, students replied that they get demotivated because of the school and other environments.

We are not allowed to stay at school after six o'clock in the evening.

The period for checking out course books [from the library] is not long enough. We have to return them quickly. And this demotivates me.

I have a family, and my baby is young. Thus, when I get home, I have no time and place to study.

I stay at my relatives'. Thus, it is difficult to study because I am the one who is responsible to do the chores at home.

The internal factors participants declared are following.

I have different wishes. For example, I prefer playing basketball rather than practicing English.

I think I don't have good time management.

Ifeel lazy and inactive.

I feel ashamed when other students speak English fluently and do well in English.

For the follow-up item 4, students answered they will be able to reach their goals of travelling, studying abroad, getting a better job, working abroad, and being self-confident and sociable.

For question item 5, interview participants they will be respected and other people's attention would change if they learned English well.

When I work as an en English teacher at secondary school, I will get respected more by pupils.

I will be a role model for other people because I have perfect English.

I will work and live in a great atmosphere and have a good surrounding of better people.

\section{DISCUSSION}

We investigated students' motivations toward learning English and the factors demotivating them, particularly to determine whether English-majoring students have instrumental or integrative orientation. The questionnaire results showed students' motivations are more instrumentally oriented than integrated. In other words, pragmatic reasons to learn English seem common among students.

In Mongolia, the demand for English teachers in the labor market has been increasing lately because the total hours of English classes in secondary education level have been increased on a national level. Furthermore, private schools have opened that offer and teach English as a foreign language from the $1^{\text {st }}$ grade. Thus, we interpret these findings on parental encouragement towards learning English, students' interests in foreign language and desires to learn English being high might be related to the social circumstances above. Likewise, since students have decided on their future profession as an English teacher, their desires and interests in English as instrumental orientations relates to their goals.

Additionally, one of the lowest mean items of the questionnaire was English class anxiety, which means they are rather confident when speaking English in class, but the students' English use anxiety is higher, which shows students worry about their use of English outside 
the class. Mongolia lacks English speaking situations and students struggle to find real-life situations in which to speak English daily, outside community and school clubs and events that offer English practice.

The focus group interview revealed factors demotivating students can be internal and external. We divide external factors affecting the motivation of learning English into teachers' attitudes and the school and classroom environment. The previous studies showed teachers factor as one of the important factors demotivating students (Ali and Pathan 2017). As for the school and classroom environment, as Ali and Pathan, Dorneyi, Kikuchi and Sakai mentioned, school or classroom environments affect students, as well.

Significant differences from the related studies include that students did not give answers related to teaching materials (Ali and Pathan 2017) or course books (Dorneyi 2001). We observed from the interview that living conditions were one of the special demotivating factors for students we interviewed. It is common for students not only staying at the university dormitory or renting a flat with other students but also staying at their relatives during their university years because students usually enroll from different aimags in Mongolia. When students stay at their relatives, they feel uncomfortable which prevents them from achieving in English and decreases their motivation toward learning English. Most of the students at NUM Erdenet School are female. There were female students who got married and have children who participated the focus group interview. From their perspective and replies, it is clear that if a female student is married and has child(ren), this prevents them from practicing and studying English. Moreover, other students' attitudes seemed to be important demotivating factors for students. For instance, students hesitate to speak or practice English when other students correct their mistakes and giggle when they make mistakes.

For internal factors, we consider some accounts. These are students' wishes, goal settings, learning and cognitive styles, formation of character and upbringing, self-confidence, and psychological conditions. Students mentioned internal motivating factor of being accepted, respected and appreciated is rather important to them because there is an intention of society that thus acquired social stand or position is favored more. The students who are Englishmajoring have high needs of esteem (Maslow 1943), where we explain this could be resulting from high appreciation and respect toward teachers as a profession and people with advanced knowledge of English.

\section{LIMITATION}

There were some limitations to this research, though it provided some results of motivation of English-majoring students towards learning English and factors affecting them demotivated. Firstly, only students at NUM, Erdenet, were surveyed. Therefore, the result may not be generalized to other university students who are English-majoring in Mongolia. Second, the number of study sample was small and thus the study scope is rather limited. 


\section{CONCLUSION AND RECOMMENDATIONS}

We aimed to determine the motivation orientation toward learning English among English-majoring students at National University of Mongolia, Erdenet School. We also intended to reveal the factors leading to demotivational attitude towards learning English.

Our findings from the questionnaire and focus group interview showed that Englishmajoring students have a higher instrumental orientation than integrative orientation toward learning English, both because they have already chosen the program as their future profession and English teachers demand in Mongolia is increasing. Moreover, their parental encouragement and desire to learn English results were strong.

Some demotivating factors include their teachers' attitudes and their school environment. Students also responded with significantly different factors which effect their learning English motivations, including living conditions and classmates' attitudes.

We recommend English teachers to pay attention to their attitudes toward students, classroom behavior, atmosphere and organization of the lessons. Teachers must provide real-life situations in class, where students can practice English more. We suggest school administrations to consider making library services more flexible. Clubs, trainings and seminars designed to develop the students personally and academically should be run and organized more often at the university.

\section{REFERENCES}

Afzal, Hasan, Imran Ali, Muhammed Aslam Khan, and Kashif Hamid. 2010. "A Study of University Students' Motivation and Its Relationship with Thei Academic Performance." International Journal of Business and Management 80-88.

Ali, Maheen Sher, and Zahid Hussain Pathan. 2017. "Exploring Factors Causing Demotivation and Motivation in Learning English Language among College Students of Quetta, Pakistan ." International Journal of English Linguistics 81-89.

Bakhshi, H, J Downing, M Osborne, and P Schneider. 2017. The future of skills employment in 2030. London: Pearson and Nesta.

Chambers, Gary N. 1993. "Taking the 'de' out of demotivation." Language learning journal 13-16.

Chen, Liu. 2014. "Attitude and Motivation for English Learning." Studies in Literature and Language 51-56.

Cohen, Roger. 2004. "The Current Status of English Education in Mongolia." Asian EFL journal . https://asian-efl-journal.com/Dec_04_rc.pdf.

Dorneyi, Zoltan. 2001. "Demotivation in foreign language learning." TESOL '98 Congress. Seattle : Longman .

—. 2018. Motivating students and teachers . y John Wiley \& Sons, Inc.

—. 2018. "Motivating students and teachers." Zoltan Dorneyi . https://b9f19ceb-f720-4252a2beccde56c0821f.filesusr.com/ugd/ba734f_7145f1216c414f6a834403ea6c54a1b3.pdf.

Dorneyi, Zoltan, and Ema Ushioda. 2011. Teaching and Researching motivation. Malaysia: Pearson Education Limited.

Fry, Heather, Steve Ketteridge, and Stephanie Marshall. 2009. A Handbook for Teaching and Learning in Hiugher Education. New York : Taylor\& Francis e-Library.

Gardner, Robert C. 2004. Robert C. Gardner. http://publish.uwo.ca/ gardner/. 
—. 2001. "Integrative Motivation: Past, Present and Future." Western Technology Services. February 17. http://publish.uwo.ca/ gardner/docs/GardnerPublicLecture1.pdf.

—. 2007. Motivation and Second Language Acquisition. Febrauary 02. https://publish.uwo. ca/ gardner/docs/SPAINTALK.pdf.

Gardner, Robert C., and Wallace E. Lambert. 1972. Attitudes and Motivation in SecondLanguage Learning . Massachusetts : Newbury House Publishers.

Jung, Sook Kyung. 2011. "Demotivating and Remotivating Factors in Learning English; A case of low level College students." English teaching 47-72.

Kikuchi, Keita, and Hideki Sakai. 2009. "Japanese Learners' Demotivation to Study English: A survey study." The Japan Association for Language teaching journal 183-204.

Klimova, Blanka Frydrychova. 2011. "Motivation for Learning English at a university level." Procedia Social and Behavioral Science 2599-2603.

Krueger, Richard A., and Mary Anne Casey. 2015. "Focus group interviewing research methods." Richard A. Krueger . https://richardakrueger.com/focus-group-interviewing/.

Maslow, Abraham H. 1943. "A theory of human motivation ." Internet Archive . https://archive.org/details/MaslowA.H.1943.ATheoryOfHumanMotivation.Psychologic alReview504370-396./page/n5/mode/1up.

MECSS. 2015. "Core program for secondray education ." Mongolian Institute for Educational Research. http://www.mier.mn/wp-content/uploads/2018/11/Suuri_tsum. pdf.

— 2016. "Core program for upper-secondary education." Mongolian Institute for Educational Research. 11. http://www.mier.mn/wp-content/uploads/2018/11/Language.pdf.

MES. 2014. "Core program for primary education." Mongolian Instirute for Educational Research. 11. http://www.mier.mn/wp-content/uploads/2018/11/Suuri_tsum.pdf.

Ministry of Education, Culture, Science and Sports. 2019. "Mongolian-English-Russian glossary of Higher Education Terminology." Renovation project of Higher education.

Mongolian Ministry of Education, Culture and Science. 2014. "Requiremet for bachelor degree programs." Mongolian Ministry of Education, Culture and Science. https://mecss. gov.mn/news/93/.

NUM, Erdenet School. 2020. "Completion report of 2015-2020 Strategic plan of NUM, Erdenet school ." Orkhon .

Ozuturk, Guluz, and Cigdem Hursen. 2014. "Determination of University students motivation in EFL classroom ." Procedia Social and Behavioral Science 7-12.

Shagdarsuren, Solongo, and Jivaa Davaasuren. 2017. "Current Situation of English language level of students at NUM, Orkhon School." Mongolian Journal of English language and Culture Studies 111-120.

Schwab, Klaus, ed. 2018. "The Global Competitiveness Report." World economic forum. http://www3.weforum.org/docs/GCR2018/05FullReport/TheGlobalCompetitivenessRe port2018.pdf.

William, Marian, and Robert Burden. 1997. "Motivation in Language Learning: A social Constructivist perspective." Les Cahiers l' APLIUT 19-27.

Zangbar, Ahmad. 2012. Mountain Scholar . https://mountainscholar.org/bitstream/ handle/10217/75302/Zanghar_colostate_0053N_11452.pdf;sequence=1. 